\title{
TWO DISTINCT ORIGINS OF THE NORTHERN SLAVE ECLOGITES
}

\author{
Maya G. Kopylova, \\ The University of British Columbia, Canada
}

\section{INTRODUCTION}

The mid-Jurassic Jericho kimberlite pipe located in the Northern Slave province (NWT, Canada) hosts abundant fresh eclogite xenoliths. The eclogites were subdivided into two groups based on the presence of massive or foliated fabric. Both of them occur interlayered with low-temperature peridotites over a depth range of 90-200 km (Kopylova et al., 1999). This paper explores the origin of the two groups of eclogites using their rare earth elements patterns and constrains the composition of the metasomatic fluids that caused intensive recrystallization of the rocks.

\section{PETROGRAPHY, BULK CHEMISTRY AND PHYSICAL PROPERTIES OF THE N SLAVE ECLOGITES}

The eclogites are composed of primary pyrope, omphacite and rutile, with occasional zircon, olivine, orthopyroxene, kyanite, apatite and ilmenite. Massive and foliated eclogites differ in mineral chemistry and bulk composition. Clinopyroxene in foliated eclogite has higher contents of jadeite and hedenbergite; garnet has higher grossular content (Kopylova et al., 1999). Only the massive eclogite with Mg-rich garnet and jadeite-poor clinopyroxene is known to contain diamond (Cookenboo et al., 1998). Primary pyrope and omphacite in the both groups of eclogites are variably altered to amphibole, phlogopite, epidote, chlorite and serpentine. Omphacite commonly show spongy rims of recrystallized, secondary clinopyroxene enriched in $\mathrm{Ti}$, $\mathrm{Ca}$ and $\mathrm{Mg}$, and depleted in the jadeitic component. Pyrope can be also overgrown by rims of late, $\mathrm{Mg} \pm \mathrm{Ti}$ -rich and Ca-poor garnet. Foliated texture is partly controlled by preferential replacement of garnet and clinopyroxene by secondary volatile-rich phases along specific planes.

Eclogite from the N Slave has compositions typical of cratonic kimberlite-derived eclogites with $12-20 \%$ $\mathrm{MgO}$ and $41-47 \% \mathrm{SiO}_{2}$. Geochemically, these deep eclogites are distinct from both MOR basalts and Archean basalts and komatiites. Foliated eclogites show higher contents of $\mathrm{MgO}, \mathrm{TiO}_{2}$ and $\mathrm{V}$ than massive eclogites; moreover, the $\mathrm{TiO}_{2}$ content of foliated eclogites exceeds that of other eclogitic xenoliths worldwide (i.e. $>1.5 \mathrm{wt} \% \mathrm{TiO}_{2}$ ). The Ti resides in rutile which has the highest modal abundance in Ti-rich samples (2-3\%). Ti-rich eclogites are also rich in $\mathrm{P}_{2} \mathrm{O}_{5}$ which is sequestered in apatite. In addition, a positive correlation of $\mathrm{Ti}$ with $\mathrm{Fe}_{2} \mathrm{O}_{3}$ (Kopylova et al., 2001) suggests that foliated samples record higher values of oxygen fugacity.

Measured seismic wave velocities and densities of the eclogite were used to estimate its seismic anisotropy (Kopylova et al., 2001). Foliated fabric in fresher eclogites could account for the $2 \% \mathrm{Vp}$ anisotropy, the $3 \%$ Vs anisotropy and the $2 \%$ Vs splitting. It cannot explain a $5 \%$ seismic anisotropy for the mantle as measured for the southwestern Slave (Bostock, 1998). Stronger anisotropy (8\%) is found only in a heterogeneous, highly altered eclogite, where a typical medium grade metamorphic association of chlorite, epidote and phlogopite makes up $65 \%$ of the former rock. In fresh eclogite samples, $\mathrm{Vp}$ and $\mathrm{Vs}$ at room temperature and pressure are $\mathrm{Vp}=7.25-7.9$ and $\mathrm{Vs}=$ $3.9-4.4 \mathrm{~km} / \mathrm{s}$, whereas in the retrograde eclogite the velocities are much lower $(\mathrm{Vp}=6.5-6.6 \mathrm{~km} / \mathrm{s})$.be weathered to clays, contain magnetite and a suite of heavy minerals including pyrope, ilmenite, and chromediopside.

\section{RARE EARTH ELEMENT CHEMISTRY AND ORIGIN OF ECLOGITES}

REE compositions of the Jericho eclogite were reconstructed from REE compositions of fresh garnet and clinopyroxene and their modal abundances. The LAM-ICP MS analysis of garnet and clinopyroxene grains was performed on an ultra-high sensitivity VG PQ II S+ ICP mass spectrometer coupled with a Merchantek LUV 266 laser ablation microprobe (LAM) (Chen, 1999). REE patterns of reconstructed premetasomatic rocks suggest two distinct protoliths, and contrasting origins of the massive and the foliated eclogite. Thus, the eclogite fabric reflects a fundamental difference between magmatic predecessors of the eclogites and their formation processes rather than being an imposed recent feature.

The foliated eclogite shows uniform LREE-depleted patterns with a small positive $\mathrm{Eu}$ anomaly and chondrite-normalized HREE contents of $\sim 10$ (Fig. 1A). The protolith of the foliated eclogite must have experienced minor accumulation of plagioclase at shallow-mid crustal levels. Its shallow origin is further 

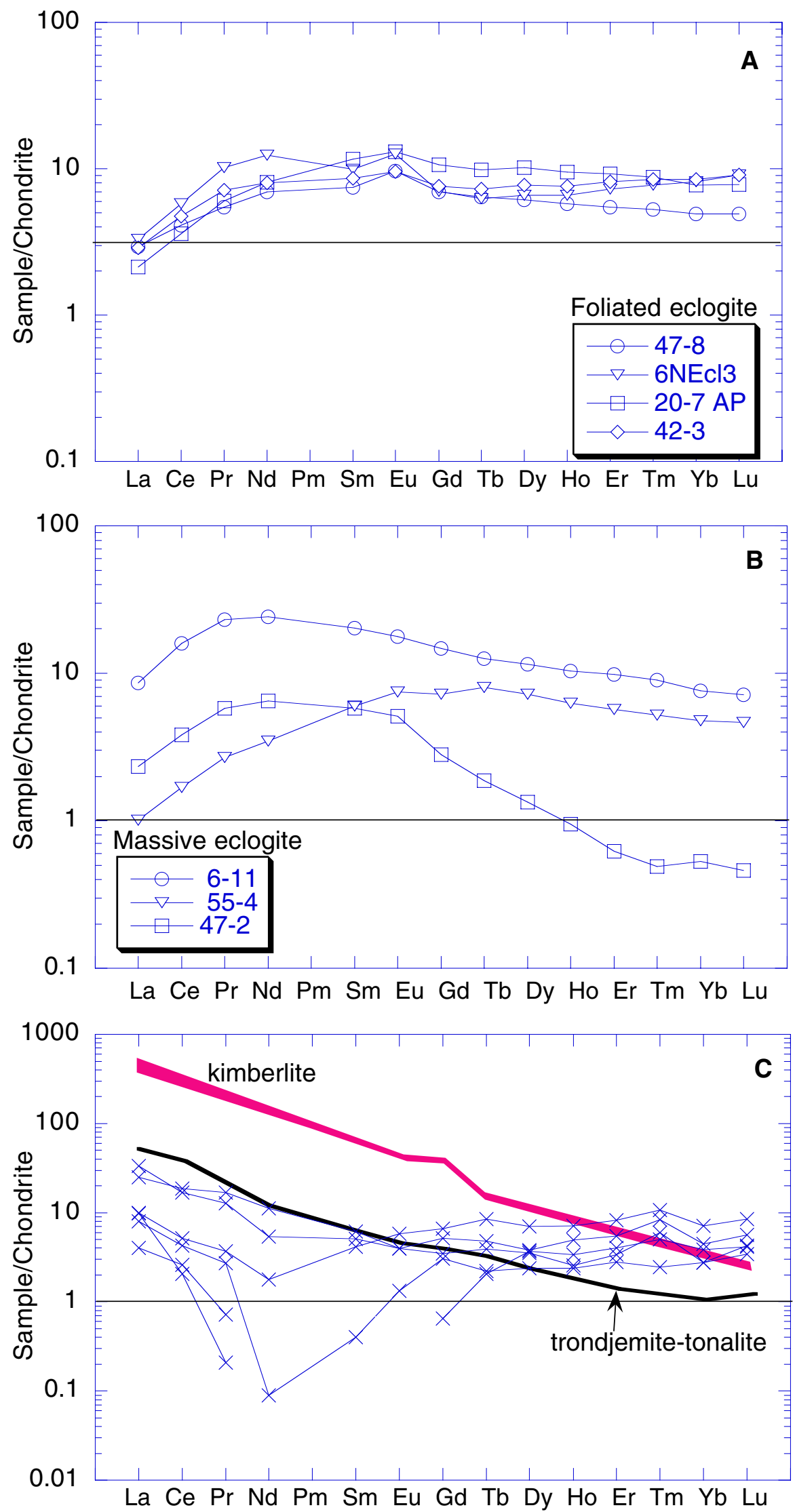

Fig. 1. Chondrite-normalized rare earth patterns for the Jericho foliated eclogite (A), massive eclogite (B) and for the metasomatic component (C). Also shown are REE patterns of the Jericho kimberlite (Price et al., 2000) and an average Archean trondjemite-tonalitegranodioritic suite (Martin, 1994). 
supported by the absence of the HREE fractionation and of equilibration with garnet that occurs deeper in the lithosphere. An origin of foliated eclogites as lowpressure mafic cumulates is consistent with all the above features. If these mafic cumulates intruded into the lower part of oceanic or continental crust, then they may never have a chance to be in contact with upper crustal sediments rich in organic carbon. The absence of abundant carbon for diamond formation may explain the absence of diamonds in the foliated eclogites.

REE patterns of the massive eclogite (Fig. 1B) are diverse and complexly shaped, indicative of more than one episode of rock formation. Massive eclogite shows medium to strong fractionation of HREE, indicative of a past coexistence with garnet as partial or fractionated melts. A deep origin of the protolith is corroborated by the absence of the Eu anomaly. The complex shapes of the REE patterns are always based on convex-upward patterns typical of eclogitic clinopyroxenes of the $\mathrm{N}$ Slave. Massive eclogites with the most pronounced upward-convex REE shapes stand out due to their high clinopyroxene modes (68-75 vol \%). Similar REE patterns of clinopyroxene were described in several suites of eclogites, pyroxenites and peridotites worldwide (Jerde et al., 1993, Barth et al., 2001). These patterns contrast with the REE patterns of clinopyroxenes crystallized from mantle magmas and are ascribed to mantle metasomatism and interaction with LREE-rich fluids (Jerde et al., 1993). Similar convex-shaped patterns are found in modally metasomatized apatite- or amphibole-bearing peridotite (Bonatti et al., 1986; O'Reilly and Griffin, 1988) and cryptically metasomatized peridotite near amphibolite pyroxenite veins (Bodinier, 1990 and references therein). They may result from disequilibrium REE partitioning associated with percolation of a LREEenriched fluid (Bodinier, 1990). Incomplete reequilibration of mantle rocks with infiltrating fluid or melt is found to cause selective LREE enrichment from a chromatographic fractionation of the melt phase (Navon and Stolper, 1987).

We conclude that the igneous precursor for the massive eclogite formed at greater depths in a complex process that involved at least two stages. Their protolith may have formed as high-P cumulates of mafic magmas that had previously undergone fractionation of garnet. Alternatively, the protoliths may have been mafic intrusives formed in the garnet stability field and metasomatised by percolating mantle fluids.

There is one other fundamental difference between the massive and the foliated eclogites. The massive eclogite occurs at mantle depths consistent with their inferred depth of melting, whereas the foliated eclogite could not have formed at depths where they are presently found $(120-190 \mathrm{~km})$. No descent to mantle depths is required for the protolith of the massive eclogite. In contrast, protoliths for foliated eclogites must have formed at shallower depths and somehow been transported deeper. Subduction of oceanic crust or sinking of delaminated lower crustal material are viable mechanisms for this process. The characteristic foliated fabric of the eclogites probably reflects the protracted metamorphic and tectonic history of their descent.

\section{GEOCHEMISTRY AND ORIGIN OF METASOMATIC COMPONENT}

REE contents of the N Slave eclogite were analyzed in powdered whole-rock samples by ICP-MS. As expected, there is a difference between the bulk REE compositions of the eclogite reconstructed from primary minerals and those derived from analyses of bulk rock powder. The difference between them (Fig. 1C) is the result of the addition of a metasomatic component. The metasomatically-added material resides in secondary minerals and intergranular films; most rare earths concentrate in secondary phlogopite, amphibole and minor apatite. The metasomatism affected both groups of eclogites.

The REE pattern of the metasomatic component displays 5-30 times enrichment in LREE and flat patterns in HREE. However, the LREE enrichment and REE fractionation were not extremely strong, as is typical of alkaline magmatism and kimberlites. A strong fractionation in HREE (Fig. 1C), characteristic of fluids in equilibrium with deep-seated garnet-bearing mantle rocks, is also absent. The pattern does not resemble that of trondjemite-tonalite-granodiorite (TTG) melts or host Jericho kimberlite (Fig. 3C). We conclude that the metasomatism was probably not related to the major Archean melting events that produced cratonic TTG suites, or to the later kimberlite formation.

The La content of the metasomatic material correlates well with bulk $\mathrm{K}, \mathrm{Rb}$ and $\mathrm{Th}$ contents of the eclogites and with the cumulative mode of secondary phases (Kopylova et al., 2001) that include Ti-rich diopside, Ti-rich pyrope, amphibole, phlogopite and chlorite. On this basis, it appears that late metasomatic fluids charged with $\mathrm{K}, \mathrm{Rb}$, Th and LREE caused the recrystallization of clinopyroxene and garnet and the development of secondary hydrous phases. 


\section{REFERENCES}

Barth , M.G., Rudnick, R.L., Horn, I., McDonough, W.F., Spicuzza, M.J., Valley, J.W., Haggerty, S.E., 2001. Geochemistry of xenolithis eclogities from West Africa, Part I: A link between low $\mathrm{MgO}$ eclogites and Archean crust formation. Geoch. et Cosmoch. Acta, 65, 9, 14991527.

Bodinier, J.L., Vassuer, G., Vernieres, J., Dupuy, C., Fabries, J., 1990. Mechanisms of mantle metasomatism: geochemical evidence from the Lherz orogenic peridotite. J. of Petrology, 31, 597-628

Bonatti, E., Ottonello, G., Hamlyn, P.R., 1986. Peridotities from the island Zabarzad (St. John), Red Sea: petrology and geochemistry. J of Geophysical Research, 91, 599631

Chen, Z, 1999. Inter-element fractionation and correction in laser ablation ICPMS. Journal of Analytical Atomic Spectrometry, 14: 1823-1828

Bostock M.G, 1998. Mantle stratigraphy and evolution of the Slave province. J. Geoph. Res., 103 B9, 21183-21200

Cookenboo H., Kopylova, M.G. and Daoud, D.K., 1998. A chemically and texturally distinct layer of diamondiferous eclogite beneath the central Slave Craton, northern Canada. Ext. Abstracts, 7th Intern. Kimb. Conf., Cape Town, 13-18 Apr., 164-166

Jerde, E.A., Taylor, L.A., Crozaz, G., Sobolev, N.V., Sobolev, V,N, 1993. Diamondiferous eclogites from Jakutia, Siberia: evidence for a diversity of protoliths. Contrib. Mineral. Petrol 114, pp. 189-202.

Kopylova, M.G., J.K. Russell, H. Cookenboo, 1999. Mapping the Lithosphere Beneath the North Central Slave Craton. In: Proc. 7th Int. Kimberlite Conference, J.J.Gurney, S.R. Richardson, eds., Red Roof Designs, Cape Town, pp. 468-479.

Kopylova, M.G., Russell, J.K., Christensen, N.I., 2001. Composition and fabric of the N. Slave eclogite as evidence for mantle metasomatism. Ext. Abstract in "Mantle Lithosphere and Lithoprobe: Views of continental evolution from the bottom up", Lithoprobe Workshop III, October 27-29, 2001, Banff, Canada, Lithoprobe Report No. 81, p. 61-70

Martin, H., 1994. The Archean grey gneisses and the genesis of continental crust. In: K.C. Condie (ed.) Archean Crustal Evolution, Elsevier, 205-259

Navon, O., and Stolper, 1987. Geochemical consequence of melt percolation: the upper mantle as a chromatographic column. J. of Geology, 95, 285-307

O'Reilly, S.Y., Griffin, W.L., 1988. Mantle metasomatism beneath western Victoria, Australia: I. Metasomatic processes in Cr-diopside lherzolites. Geochem. Cosmochem Acta, 52, 433-447

Price, S.E., Russell J. K, and Kopylova M.G., 2000. Primitive kimberlite magmas from Jericho, NWT, Canada: constraints on primary magma chemistry. J. of Petrology, 41, 6, 789-808

Contact: MG Kopylova, EOS Dept, the University of British Columbia, 6339 Stores Rd, BC, Canada, V6T 1Z4, E-mail: mkopylov@eos.ubc.ca 